Impact Factor: 4.845(SJIF) Research Journal Of English (RJOE) Vol-4, Issue-4, 2019

www.rioe.org.in An International Peer-Reviewed English Journal

ISSN: 2456-2696

Indexed in: International Citation Indexing (ICI), International Scientific Indexing (ISI), Directory of Research Journal Indexing (DRJI) Google Scholar \& Cosmos.

\title{
NATURE IMAGERY IN ROBERT FROST'S POETRY
}

\author{
Dr. K.Surya Chandra Rao \\ Principal (FAC) \\ Govt. Degree College \\ Narasannapeta 532421 \\ Srikakulam Dt.,India
}

\begin{abstract}
:
Robert Frost is a famous American poet who used nature in his poetry to make readers think about life. Seldom would Robert Frost be given a seat in a Pantheon ofAngloAmerican modernist poets, whereas Pound, Eliot, Wallace Stevens, William Carlos Williams and Marine Moor would all have a prestigious place. For, Frost is known as a gentle farmer poet who represents New England's nature and rural folk. He is judged to be an old fashioned nature poet who criticized "the avant-garde" and continued to make use of English literary tradition.
\end{abstract}

Keywords: woods, snow, frozen lake, horse, harness, flake, wall

Introduction

Robert Frost was born on March 26 $6^{\text {th }}, 1874$ in San Francisco, California.Though his ancestry was of New England and at the age of ten, when his father died, he returned to New England with which his name is mostly associated.He was a bobbin boy in a mill, worker in a shoe factory, reporter of a news paper, farmer and country school master. Frost was admired for his depictions of rural life of New England, his command of American colloquial speech, and his rustic verse portraying ordinary people in everyday situations. He has indeed been the most honoured of the American poets. He received the Pulitzer prize four times(1924,1931,1937 and 1943).

Pound made a patronizing joke about Frost's local colour. He also called 'dull and old fashioned" Frost "backwards, even a barnyard poet" and appraised his books of New England eclogue'In Lowell's patronizing light, Frost is deficient in cosmopolitan sophistication, but good enough to be recognized as a genuine local colour poet who presents photographic realism of New England life.

Frost's use of nature is the single most understood element of his poetry as he himself said, "I am not a nature poet. There is almost always a person in my poems."Most of Frost's poems use nature imagery. His grasp and understanding of nature is well recognized. Frost like William Wordsworth isn't attempting to inform North American country however nature 
Impact Factor: 4.845(SJIF) Research Journal Of English (RJOE) Vol-4, Issue-4, 2019

www.rjoe.org.in An International Peer-Reviewed English Journal

ISSN: 2456-2696

Indexed in: International Citation Indexing (ICI), International Scientific Indexing (ISI), Directory of Research Journal Indexing (DRJI) Google Scholar \& Cosmos.

works. His poems ar concerning human scientific discipline. Rural scenes and landscapes, homely farmers and also the nature are wont to illustrate a psychological struggle with everyday expertise met with courageousness, can and purpose within the context of Frost's life and private scientific discipline. His perspective is stoic, honest and accretive. Frost uses nature as a background. He typically begins a verse form with AN observation of one thing in nature and so moves toward a association to some human state of affairs or concern. Frost's poetry notably brings to attention the social problems relied upon the human means that provides the message of man for human race.

In the verse form "Stopping by woods on a Snowy Evening" nature is expressed heaps. Frost's terribly initial sentence talks concerning words. Here we discover him as a nature lover WHO likes to take a seat and watch the blizzard. But in the last stanza he says that life is more important to him than being tempted by the beauty of woods. He says:

"The woods are lovely, dark and deep

But I have promises to keep

And miles to go before I sleep,

And miles to go before I sleep.

In the above lines, we find Frost's deep philosophical connotation, where the poet reminds himself of his obligations to himself and to his fellow beings. "And miles to go before I sleep" is a symbol for life's journey which ends in eternal sleep that is dark. Here the "sleep"becomes a deserved honour. "The woods"is a complex symbol. It symbolizes deep gratification as well as the dark inner self of man.In his poetry, Frost's facts are correct, especially in botanical and biological terms. His poetic impulse startswith some psychological concern and finds its way to a material embodiment which usually includes a natural sense. Frost always takes time to describe it with sensitivity and care while using good poetic technique especially figurative language.

In another poem "Mending Wall"nature is shown to present the barrier of today's world. The "wall"between Frost's apple orchard and his neighbour's pine wood suffers damage during a winter. During the next spring the poet and his neighbour meet to repair it and walking along each on his side of the wall they replace the fallen stones. The poet feels that repairing the wall is meaningless. But his neighbour replies that "good fences make good neighbours". The central situation of the poem has given scope to a social or symbolic interpretation and cultural problems have been analyzed as well. He reveals the realistic picture of the society. He shows the right path and way of life where man is thoroughly invisible in day today life. In "Birches, Frost gives us a nostalgic view of his Childhood when he used to swing the birches as a boy. To talk about the weariness and the despair of his life Frost uses nature in this poem. He compares human life with a pathless wood. 
Impact Factor: 4.845(SJIF) Research Journal Of English (RJOE) Vol-4, Issue-4, 2019

www.rioe.org.in An International Peer-Reviewed English Journal

ISSN: 2456-2696

Indexed in: International Citation Indexing (ICI), International Scientific Indexing (ISI), Directory of Research Journal Indexing (DRJI) Google Scholar \& Cosmos.

He says:

"So was I once myself a swinger of birches,

And so I dream of going back to be.

It's when I'm weary of considerations,

And life is too much like a pathless wood"

The contrast between man and nature is the central theme of Frost's nature poetry. Frost views nature as essentially alien. He keeps himself confined with earthly region, with mundane phenomena; he is not willing to transcend the boundary of this earth. Instead of exploring the margin where emotions and appearances blend, he looks at nature across an impassable gulf. What he sees on the other side is an image of a hard, impersonal reality; man's physical needs, the dangers facing him, the realities of birth and death, and the limits of his ability to know and to act are shown in stark outline by the indifference and inaccessibility of the physical world in he must live.

Frost's poetry is abundant in the depiction of American ideals and traditions. He successfully incorporates these ideals by portraying the rural communities of New England in his poetry. Hard work for survival, interest and dedication to duty and responsibilities are such as the major ideals in most of his poems. For example, the poem "Stopping by woods on a Snowy Evening" (1923) is a rich poem containing the theme of importance of duty and responsibility against the narrator's desire to spend his time in the jocund company of nature. The poems like "After Apple Picking" and "Mowing" are the best examples to notice how the characters are interested in Physical labour.

Nature in Frost's poetry, is seen not only as a back ground tool to add beauty and charm but also more inspiring element both in constructive and destructive ways. The pastoral scenes, which he depicts in his poetry, are his experiences during his life time in New England. The noteworthy thing in his pastoral poetry is that he never limits poetry to the pastoral themes like sheep and shepherd but concentrates more on the changing scenario of the natural world in the real sense. For instance, the poem "After Apple Picking"(1914) depicts the conflict of the changing seasons. Thus, nature inFrost's poetry is unlike in the poetry of the Romantics.

Though Frost often goes for description of nature in the beginning of some of his poems, the ultimate theme of the poem ends in reality. This realistic approach of Robert Frost towards life brought name and fame as the four-time winner of Pulitzer prize.Coming to the bitter reality of the human life, Frost says fancy can accommodate with a temporary relief and every individual has to come back to the reality to bear with every pain and gain on the earth itself. The poet's view about the earth is also interpreted here as the place for real love by sharing his feelings with others around. 
Impact Factor: 4.845(SJIF) Research Journal Of English (RJOE) Vol-4, Issue-4, 2019

www.rioe.org.in An International Peer-Reviewed English Journal

ISSN: 2456-2696

Indexed in: International Citation Indexing (ICI), International Scientific Indexing (ISI), Directory of Research Journal Indexing (DRJI) Google Scholar \& Cosmos.

Frost's success as a poet lies in the selection of his subjects which are mostly the real struggles of the real people. Frost's main focus never swerves from the path of 'truth' and he concentrates on the subjects like every day activities, duty, hard work and responsibilities of the individuals in pursuit of the portrayer of the universally accepted realism in his poetry.

References:

- Frost, Robert. Collected Poems, Prose and plays Ed. Richard Poirier and Mark Richardson. New York: The library of America,1995, print

- Frost, Robert, Our Hold on the Planet: The Norton Anthology of Poetry. $3^{\text {rd }}$ edition.

- Lynen. John F. The Pastoral Art of Robert Frost. (New Heaven: Yale University Press), 1960.

- Meyers, Jeffrey. Robert Frost: A Biography. New York: Houghton Mifflin,1996 print 